\title{
FEATURES OF USING A COMPLEX HEATING SYSTEM WITH PHASE- TRANSITIONAL THERMAL ACCUMULATOR DURING THE PRE-START AND AFTER-START VEHICLE ENGINE HEATING UNDER ITS
}

\author{
V. Volkov, Prof., D. Sc. (Eng.), I. Grytsuk, Assoc. Prof., Ph. D. (Eng.), \\ Kharkov National Automobile and Highway University
}

Abstract. The article deals with the features of applying a vehicular engine complex heating system with a phase-transitional thermal accumulator. The article describes the structure of information package for studying the internal combustion engine of the vehicle equipped with a complex heating system and thermal accumulator during the pre-start and after-start heating.

Key words: complex heating, vehicular engine, pre-start and after-start heating, heating processes, vehicle, measuring complex, specifications.

\section{ОСОБЛИВОСТІ ЗАСТОСУВАННЯ КОМПЛЕКСНОЇ СИСТЕМИ ПРОГРІВУ З ТЕПЛОВИМ АКУМУЛЯТОРОМ ФАЗОВОГО ПЕРЕХОДУ В ПРОЦЕСАХ ПЕРЕДПУСКОВОГО І ПІСЛЯПУСКОВОГО ПРОГРІВУ АВТОМОБІЛЬНОГО ДВИГУНА В УМОВАХ ITS}

\author{
В.П. Волков, проф., д.т.н., І.В. Грицук, доц., к.т.н., \\ Харківський національний автомобільно-дорожній університет
}

Анотація. Розглядаються особливості застосування комплексної системи передпускового $і$ післяпускового прогріву автомобільного двигуна з тепловим акумулятором із фазовим переходом з використанням розробленого інформащійного комплексу.

Ключові слова: комплексний прогрів, транспортний двигун, передпусковий і післяпусковий прогрів, режими прогріву, транспортний засіб.

\section{ОСОБЕННОСТИ ПРИМЕНЕНИЯ КОМПЛЕКСНОЙ СИСТЕМЫ ПРОГРЕВА С ТЕПЛОВЫМ АККУМУЛЯТОРОМ ФАЗОВОГО ПЕРЕХОДА В ПРОЦЕССАХ ПРЕДПУСКОВОГО И ПОСЛЕПУСКОВОГО ПРОГРЕВА АВТОМОБИЛЬНОГО ДВИГАТЕЛЯ В УСЛОВИЯХ ITS}

\author{
В.П. Волков, проф., д.т.н., И.В. Грицук, доц., к.т.н., \\ Харьковский национальный автомобильно-дорожный университет
}

\begin{abstract}
Аннотация. Рассматриваются особенности применения комплексной системы предпускового и послепускового прогрева автомобильного двигателя с тепловым аккумулятором с фазовым переходом с использованием разработанного информаџионного комплекса.
\end{abstract}

Ключевые слова: комплексный прогрев, транспортный двигатель, предпусковой и послепусковой прогрев, режимы прогрева, транспортное средство.

Introduction

Vehicular engine starting characteristics are estimated by limit temperature of reliable start and the time needed to prepare for load. In practice, therefore, the operation of vehicular engine during pre-start development, start and post-start heating at low temperatures is differentiated, namely, the idle heating, the operational heating, heating during the load, etc. 


\section{Analysis of publications}

Previous experimental and computational studies have shown that it is appropriate to use heating system (HS) of ICE to ease the start and to rapidly heat the engine coolant [1]. Thermal accumulator (TA) with heat accumulating material and a phase transition was developed for this purpose [2-4] It allows us to accumulate thermal energy of exhaust gases.

The amount of heat accumulated by TA corresponds with the required amount of thermal energy needed for the preheating of engine coolant from the lowest outside temperature to the coolant temperature at which the load may be held $[1,3,4]$.

Heating systems have been widely applied in the processes of pre-start development and heating of vehicular ICE $[1,2]$. The peculiarity of heating systems with phase-transitional TA $[3,4]$ is mutual involvement of both heating control system and the driver, using relevant devices readings, in the pre-start and the subsequent afterstart heating of the engine.

The efficiency of HS with TA of manual control directly depends on the participation of the person in the process of heating and monitoring engine performance parameters. To ensure high efficiency of HS in a distant mode the information of OBD (On Board Diagnostic) system should be taken into account, especially the information obtained by scanning memory of onboard computer of the vehicle using special technology [5-7].

The analysis of reference sources showed that the research on the estimation of time and modes of thermal development in engine prestart and after-start heating with the HS using phase-transitional TA was not carried out. A measuring system, providing distance monitoring of engine and vehicle engineering data within intelligent transport systems (ITS), was not developed for this research $[5,7]$.

\section{Purpose and problem statement}

The purpose of this work is to develop the characteristics of the thermal preparation of the vehicle through a comprehensive system during the pre-start and after-start heating vehicle engine with battery thermal phase transition from using the information developed complex.

\section{The development of pre-start and after-start} heating processes of vehicular engine

Fig. 1 illustrates a system to control the process of pre-start and after-start heating (PSASH) of the engine and the vehicle during their operation. Under appropriate operating conditions the choice of a particular method of PSASH of the vehicular engine and the vehicle can be defined as the decision-making of the selection and application of the method to improve the engine and the vehicle. It is done during combined heating with the use of modern onboard information diagnostic system (OIDS) within ITS. The corresponding decision about using the method can be made only on the basis of determination of optimal PSASH formation under appropriate operating conditions. The final decision about the PSASH is not decisive because the best option must be determined in each case.

The presented system (Fig. 1) shows two interrelated components of the process during PSASH control - information and energy. The information component includes identification, monitoring, diagnosing and forecasting of engine and vehicle PSASH. The energy component includes engine and vehicle PSASH in operation.

The peculiarity of information interaction of PSASH processes is stated in Fig.1 (stages 1 and 4). The energy process of PSASH is done on the basis of information received from the engine and the vehicle in the process of their identification, monitoring, diagnosing and forecasting of optimal temperature condition of ICE and the vehicle (stage 1). The identification of thermal parameters, technical state of ICEs and vehicles is carried out using OIDS and overall monitoring system within ITS. The abovementioned processes are accompanied by data gathering during the monitoring process, the assessment of boundary values, time optimization of values of temperature condition parameters of ICE and the vehicle. At the end of stage 1 the compliance of ICE and vehicle PSASH with operating conditions is examined.

In step 4, the information component of the formation process of engine and vehicle PSASH can provide the estimation of boundary values of parameters, the optimization and forecasting of technical condition of ICE and the vehicle, the verification of compliance of the current technical condition with operating conditions and 
with requirements of the manufacturer or contracting authority (operator) of ICE and vehicle (apart from the above-mentioned possibilities). In addition, it can carry out diagnostics of ICE and vehicle conditions according to received parameters.

Based on the information obtained at stage 1, energy control process is carried out to ensure engine and vehicle PSASH using combined heating system (CHS). It uses environmentally sound technology of transport operation based on the theory of heat accumulation and phase transition processes [2-4]. In full size CHS is a set of subsystems, elements and means for ther- mal development and keeping engine and vehicle PSASH based on phase-transitional TA adapted to operating conditions. Among the PSASH processes with the use of CHS the following processes can be distinguished (Fig.1 bottom-left): the formation of heat accumulating material (HAM), the formation of HAM operating modes, the formation of phase-transitional thermal accumulator, and the formation of CHS with phase-transitional thermal accumulator. These processes may involve not only the formation of control algorithms and software to control engine and vehicle TA or CHS, but the formation of elements and their components (Fig. 1 bottom-right).

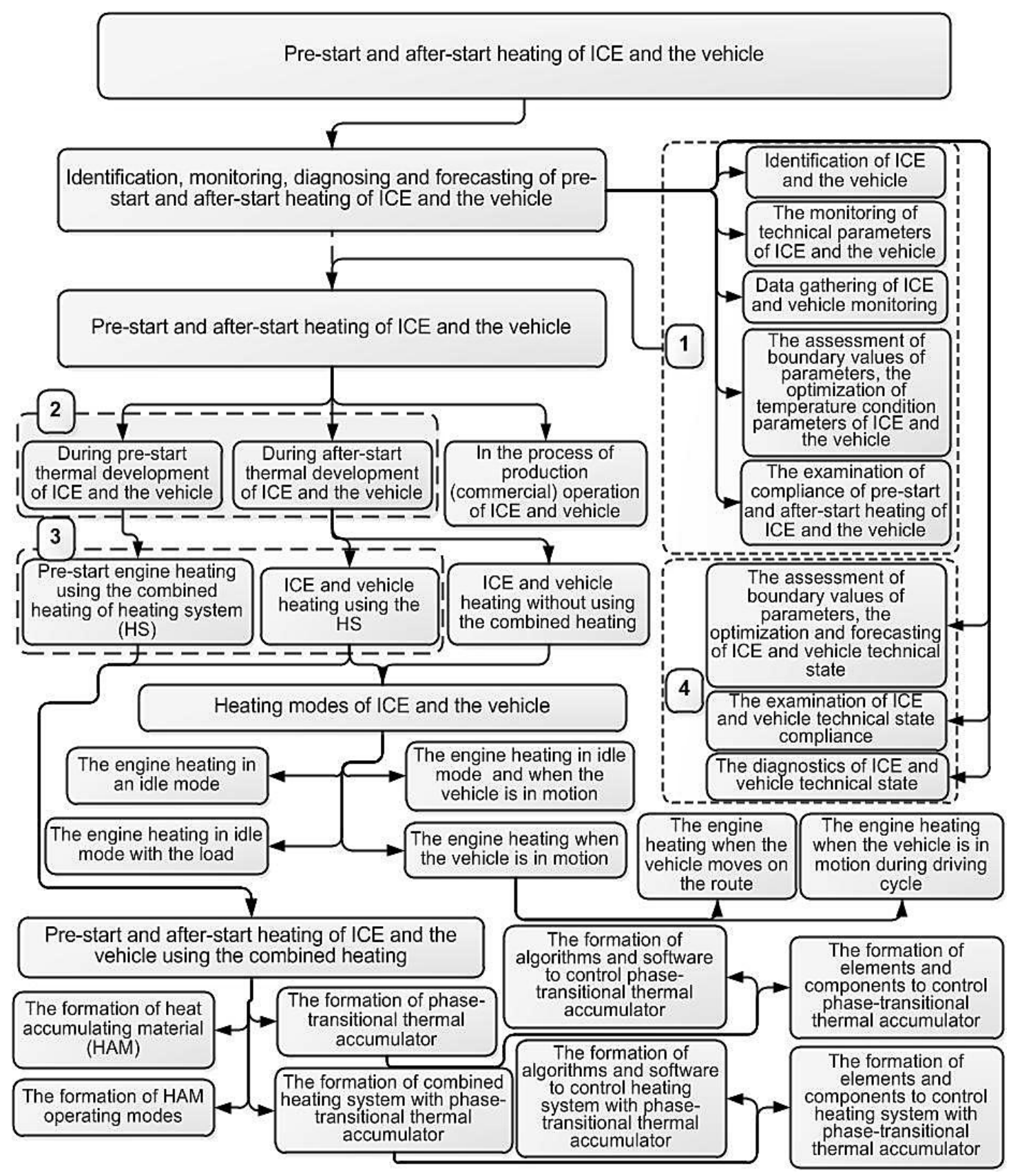

Fig. 1. The system of pre-start and after-start heating of the engine and the vehicle in operation 
The general process of PSASH during engine and vehicle operation can be split into the following components (stage 2): pre-start and afterstart processes of thermal development and industrial (commercial) process of ICE and vehicle operation. The process of pre-start heating of ICE without actual idle operation of the engine can be realized only through the use of the developed CHS (the interaction of stage 2 and stage 3) according to the above-mentioned process options.

During the process of after-start thermal development of the engine and the vehicle, it is possible to use either standard ICE and vehicle systems or CHS (stage 3). During industrial (commercial) process of ICE and vehicle operation, CHS is used only when it is not possible to maintain engine and vehicle PSASH in a corresponding range under operating conditions.

To ensure thermal development of the engine and the vehicle under operating conditions, the authors suggested to investigate after-start heating of ICE and vehicle in various modes of vehicle operation (both steady and transitional modes of the engine when the vehicle is stopped and when in motion (driving cycle and moving on the route). The basic modes of vehicular engine thermal development, studied by the authors, are the following: the engine heating in an idling mode when the vehicle is stopped; the engine heating in an idling mode with the load when the vehicle is stopped; the engine heating in an idling mode when the vehicle is stopped and then in motion of the vehicle; the engine heating when the vehicle is in motion.

\section{The formation of information package to study vehicular ICE with heating system and thermal accumulator in start and after-start heating processes}

The basic concept of an intelligent vehicle lies in its constant ability to monitor the actions of the driver, the vehicle and the environment, and to help the driver operate the vehicle most effectively and safely in the most difficult situations. It is, in fact, the assistant («backup driver») which helps the driver operate a vehicle [8]. In addition, the vehicle is in constant interaction with the environment, road infrastructure and other vehicles moving in traffic flow. Thus, the vehicle in traffic flow must be identified by road infrastructure and take part in monitoring its technical parameters and specifications for ap- propriate traffic management in accordance with the law [5].

OIDS was designed for research and estimation of ICE and vehicle heating during starting and heating. It is necessary for ICEs and vehicles, therefore, to measure the following parameters (when the vehicle is stopped and in motion): vehicle speed, rotation speed, fuel consumption, excess air ratio, coolant temperature, catalyst temperature, the voltage on the $\mathrm{O}_{2}$ catalyst sensors, absolute value of engine load; pressure in the intake manifold, intake air temperature, onboard network voltage - battery charge and control system supply, etc., for HS with TA heat-carrier temperature in TA, $t^{\circ} \mathrm{C}(\mathrm{T}, \mathrm{K})$, and for the vehicle - heat-carrier temperature (air) in different areas of a cabin, $t_{c}{ }^{\circ} \mathrm{C}(\mathrm{T}, \mathrm{K})$. These parameters are measured by standard sensors used in the control system of the engine and the vehicle. Additional specific sensors may be installed when there is a need to measure additional parameters of the engine and the vehicle. This problem is currently solved by using distance monitoring within ITS of the processes of heating heat-carriers, engine systems and a cabin during pre- and after-start thermal development of ICE at the temperature not lower than $50^{\circ} \mathrm{C}$ to provide the possibility for external load. The engine HS [1] provides the possibility and means of distance informing the driver (operator) about the current state of heat-carriers temperature and corresponding heating processes of ICE and vehicle which are carried out according to a special algorithm of engine HS operation.

To receive the necessary information about thermal processes at a distance during starting and heating the vehicular engine «on-line», it was suggested to equip the vehicle with OBDscanner and tracker and to connect the necessary sensors as functional additions [1].

The period of tracker survey of all connected sensors (both from OBD-scanner and tracker) required to control the engine thermal processes (temperature sensors) are regulated. As the temperature sensor in engine HS a digital thermometer DS18S20 was used. The values of the measured parameters were displayed on the server and on a remote computer.

The developed scheme of information exchange between the elements of the measuring complex is illustrated in Fig. 2. It is needed for distance study of ICE operation and the process of heat- 
ing a cabin of the vehicle with HS and TA during pre- and after-start heating.

Experimental studies of pre- and after-start development were conducted on gasoline engine of G4GC (4FS 8,2 / 9,35) of KIA CEE'D 2,0 $5 \mathrm{MT} 2$, equipped with a combination HS based on phase-transitional TA with heat accumulating material. The above-mentioned intelligent diagnostic system [1, 7, 9] was used in the research for distance monitoring of parameters of engine and vehicle operation processes in real time.

To facilitate the formation and use of the measuring complex of a vehicle with ICE, engine HS with TA, sensors, series of OBD-II standard system, sensors installed additionally form a set of internal networks of a vehicle (Fig. 2).

To ensure the process of heating control of vehicular engine and cabin, HS was equipped with a control system block ensuring optimal temperatures of a coolant in ICE. It provides the direct control of temperature condition of ICE and vehicle through its constituent elements (Fig. 2) and transmits the necessary information via a controller scanner-tracker to the developed information exchange system [10]. Complex ex- change of information is carried out through GPS, a-GPS, GLONASS, SBAS, GPRS, Internet or LAN that allows the transmission of digital video- and voice data. OIDS is an intelligent device that can independently solve problems of controlling technical parameters of a vehicle in motion. A fragment of report - files of monitoring with technical information about the vehicle in the form of tables, is illustrated in Fig. 3.

Baseline data for OIDS, including the parameters of vehicle, ICE, HS and TA, are put into the memory of OIDS. A comparison of data about vehicle location and specified operation criteria allows the OIDS to make its own decisions with regard to informing both the driver and the operator of the automated workplace of intranet and the participants of ICE and vehicle testing and research about the deviation from the set parameters. Bidirectional communication is carried out for operational control convenience. TA (Fig. 4) of engine and vehicle HS has the following features. The frame of TA is made of stainless steel. It has one main section with a heat exchanger to charge it from the exhaust system of the engine and a heat exchanger to transfer the accumulated heat from TA to the cooling system of the vehicular engine.

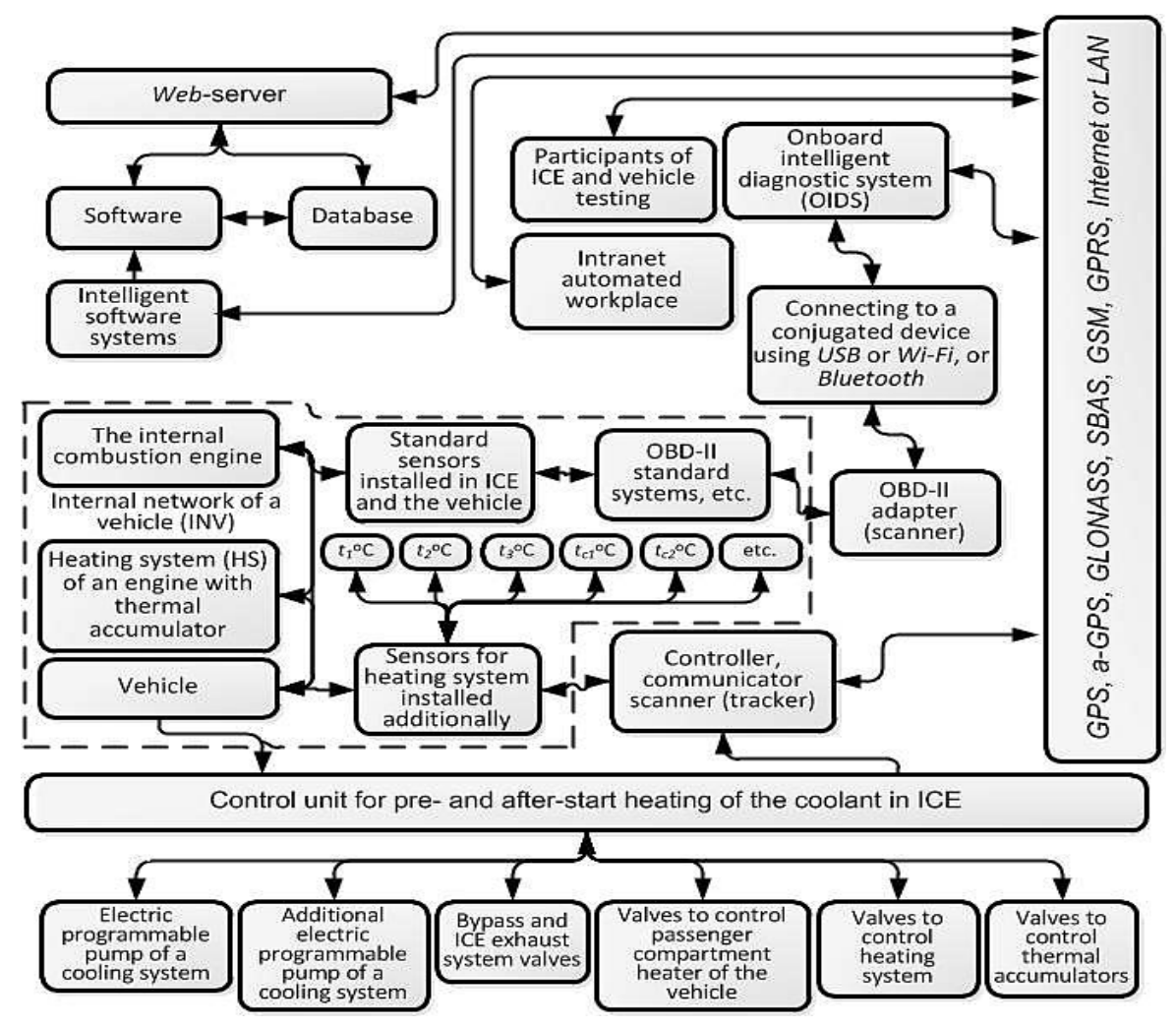

Fig. 2. The scheme of information exchange between the elements of the measuring complex for distance measurements of engine and vehicle heating with HS and TA in the process of pre- and after-start heating 
The fragment of the program window with technical information on vehicle parameters
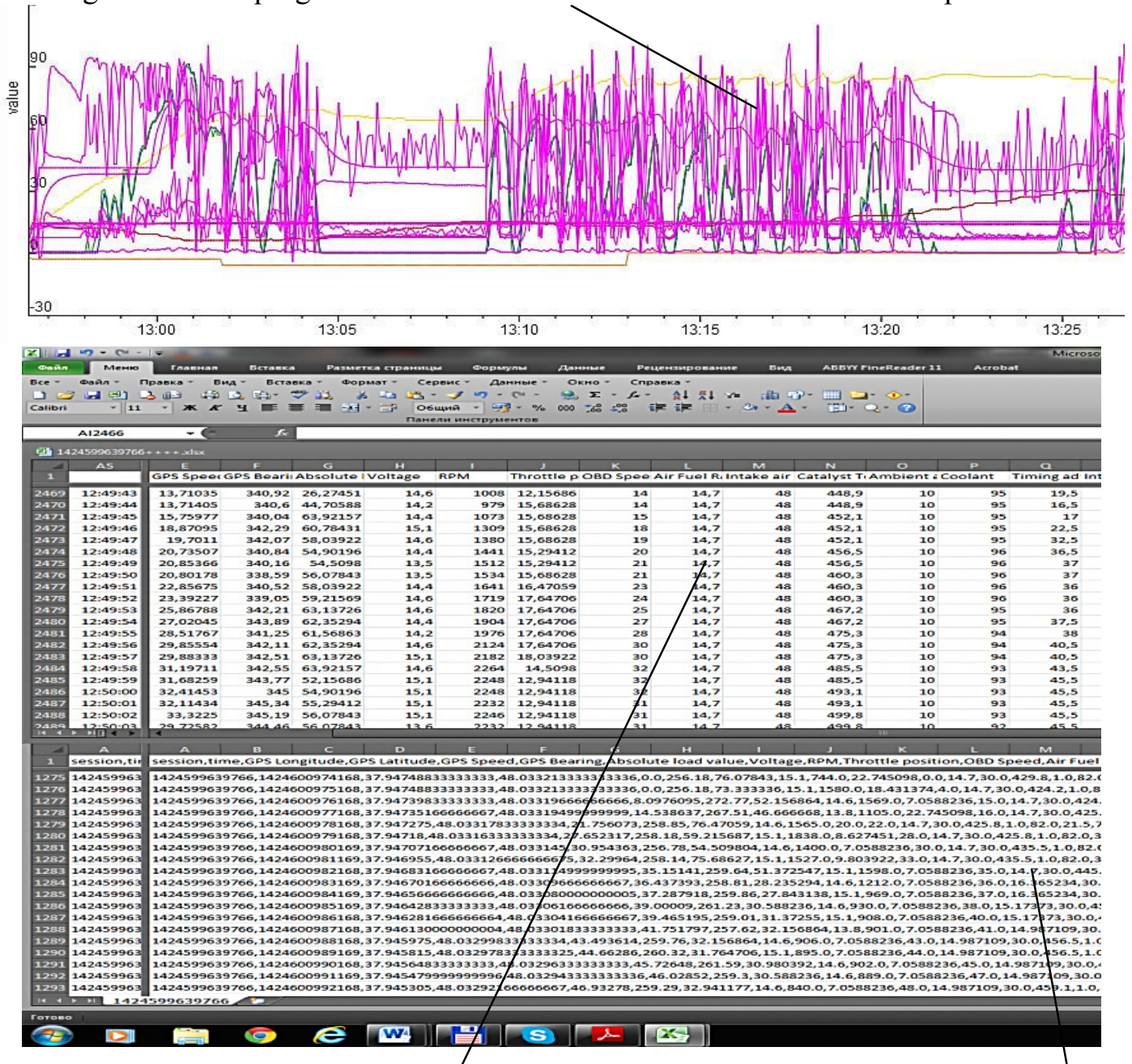

The fragment of the program window with technical information on the vehicle in .csv. format

The fragment of the program window with technical information on the vehicle in .xlsx. format

Fig. 3. The program window of the monitoring system for vehicles

Heat exchangers are made of brass. Branch pipes in TA are connected with compensators of thermal expansion of HAM and joints of thermocouples. To reduce gas-flow resistance inlet and outlet pipes have conical adapters. In the tested vehicle, TA is connected to the exhaust system by using additional heat exchanger (it is adjusted for the exhaust stream of no more than $40 \%$ ) in the exhaust system of the engine and controlled shut-off valves (shutters). Meanwhile, it is connected to the engine cooling system through the heat exchanger of the car interior. In order to reduce heat losses while testing, the TA outer surface was insulated twice with a double layer of polyethylene foam coated on both sides with layers of aluminum foil. During the 16,5 hours at $-20{ }^{\circ} \mathrm{C}$ (during the 36 hours at $+20{ }^{\circ} \mathrm{C}$ ) after engine off can the thermal energy (from 150 to $140 \pm 2{ }^{\circ} \mathrm{C}$ ) be stored in cold ambient conditions. The overall control of the engine coolant temperature was provided by standard sensors of the vehicle. To study the components of the HS thermocouples and sensors were used, according to Fig. 2. Schematic diagram of TA is shown in Fig. 4, 5.

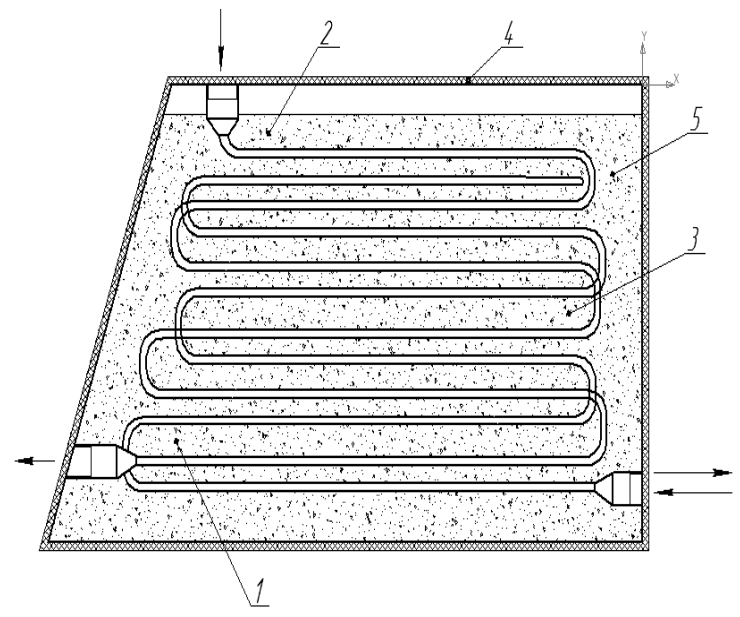

Fig. 4. Schematic diagram of TA: 1, 2, 3 placement of thermocouples, 4 - an insulation layer, 5 - HAM 
Table 1 TA specifications and HAM properties

\begin{tabular}{|l|c|}
\hline \multicolumn{1}{|c|}{ Title } & Specification \\
\hline TA heat capacity, $\mathrm{kJ} / \mathrm{K}$ & 46,25 \\
\hline TA dimensions, $\mathrm{mm}$ & $164 \times 280 \times 480$ \\
\hline Weight of thermal accumulator with HAM, $\mathrm{kg}$ & 32,75 \\
\hline HAM weight, $\mathrm{kg}$ & 18,5 \\
\hline HAM properties: & high density polyethylene \\
\hline Density, $\mathrm{kg} / \mathrm{m}^{3}, \rho_{s} / \rho_{1}$ & $925 / 800$ \\
\hline Temperature of phase transition, $\mathrm{K}\left({ }^{\circ} \mathrm{C}\right)$ & $408(135)$ \\
\hline Specific heat of phase transition, $\mathrm{kJ} / \mathrm{kg}$ & 230 \\
\hline Specific heat capacity, $\mathrm{kJ} /(\mathrm{kg}-\mathrm{K}), C_{s} / C_{1}$ & $2,5 / 3,3$ \\
\hline Thermal conductivity, $\mathrm{WT} /(\mathrm{M} \cdot \mathrm{K}), \lambda_{s} / \lambda_{l}$ & $0,25 / 0,04$ \\
\hline
\end{tabular}

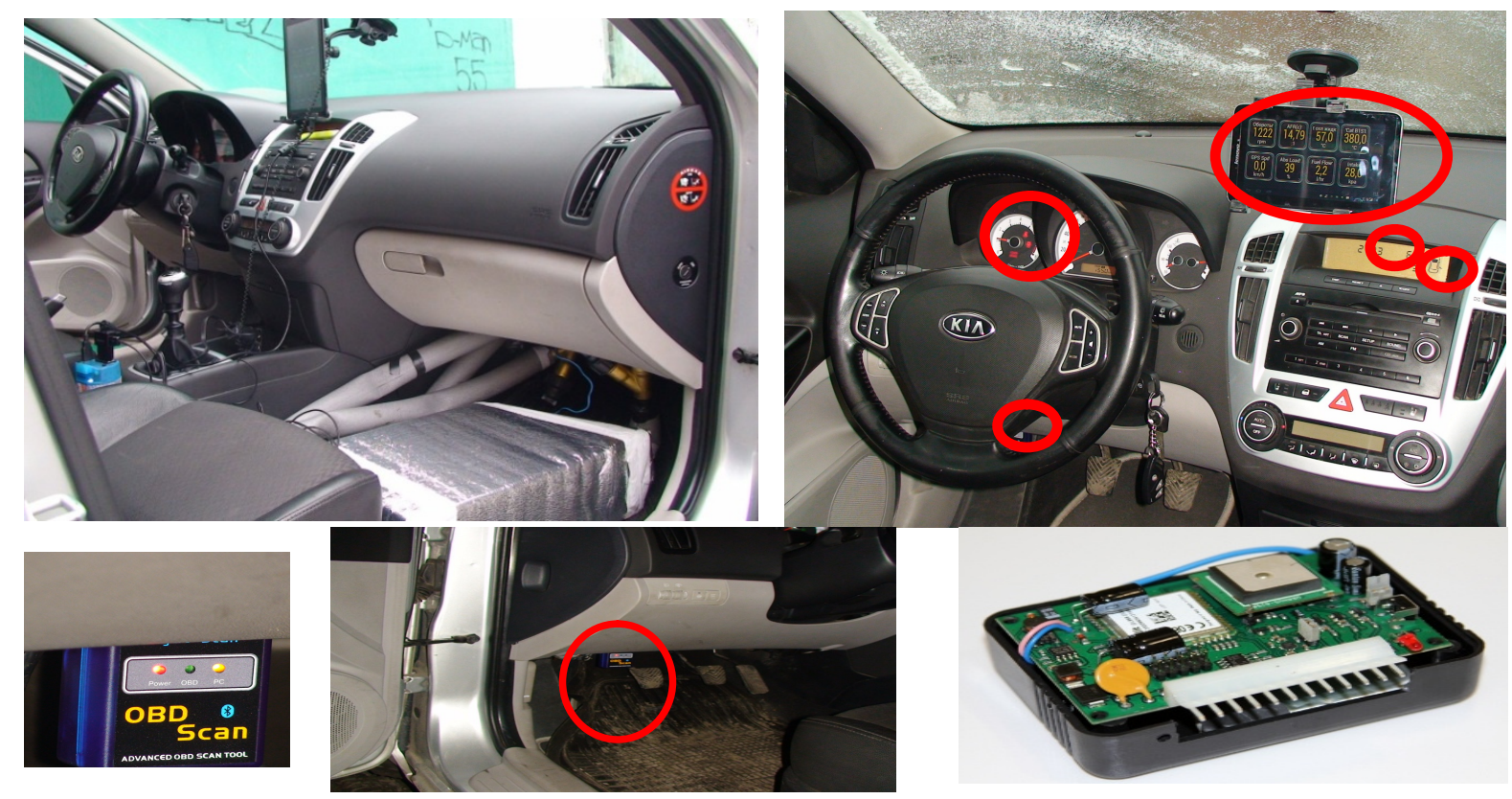

Fig. 5. A general view of a measuring complex to study the heating of the engine and the car interior with the HS and TA in pre-start and after-start heating

TA specifications and HAM properties are given in Table 1. A general view of a measuring complex to study the heating of G4GC (4FS 8,2/ 9,35) engine of KIA CEE'D 2,0 5MT2 and its interior with the HS and phasetransitional TA in pre-start and after-start heating is shown in Fig. 5.

\section{Conclusions}

The development of pre-start and after-start heating processes of vehicular engine was considered. A system of forming pre-start and afterstart heating of the engine and the vehicle in operation was developed. The structure of the unified monitoring system was designed for the vehicles equipped with CAN-tire. Furthermore, the scheme of information exchange for studying the operation of vehicular engine with HS and TA in the process of start and after-start heating was developed.

\section{References}

1. Шульгин В.В. Тепловые аккумуляторы автотранспортных средств / В.В. Шульгин. - С.Пб.: Издательство политехн. ун-та, 2005. -268 с.

2. Вашуркин И.О. Тепловая подготовка и пуск ДВС мобильных транспортных и строительных машин зимой / И.О. Вашуркин. - С.Пб.: Наука, 2002. - 145 с.

3. Левенберг В.Д. Аккумулирование тепла / В.Д. Левенберг. - М.: Наука, 1991. - 84 с. 
4. Бекман Г. Тепловое аккумулирование энергии / Г. Бекман, П. Гилли ; пер. с англ. - М.: Мир, 1987. - 272 с.

5. Информационные технологии на автомобильном транспорте / В.М. Власов, А.Б. Николаев, А.В. Постолит, В.М. Приходько; под общ. ред. В.М. Приходько; МАДИ (Гос. техн. ун-т). - М.: Наука, 2006. -284 c.

6. Приходько В.М. Формирование функциональных возможностей интеллектуальной транспортной системы для автомобильного транспорта / В.М. Приходько, С.М. Мороз, А.Н. Ременцов // Журнал Автомобильных Инженеров. - 2011. №4 (69). - С. 23-27.

7. Волков В.П. Интеграция технической эксплуатации автомобилей в структуры и процессы интеллектуальных транспортных систем: монография / В.П. Волков, В.П. Матейчик, О.Я. Никонов и др.; под ред. В.П. Волкова. - Донецк: Ноулидж, 2013. - 398 c.

8. Иванов А.М. Перспективы развития интеллектуальных бортовых систем автотранспортных средств в Российской Федерации / А.М. Иванов, А.Н. Солнцев // Журнал Автомобильных Инженеров. 2010. - №6 (65). - C. 14-19.

9. Пржибыл П. Телематика на транспорте / П. Пржибыл, М. Свитек; под ред. проф. В.В. Сильянова. - М.: МАДИ (ГТУ), 2003. - 540 c.

10. Овсянников С.И. Обоснование структуры измерительного комплекса для проведения тяговых испытаний мотоагрегатов / С.И. Овсянников // Автомобіль і електроніка. Сучасні технології: електронне наукове фахове видання. - 2012. Вип. 3. - Режим доступу http: // www. khadi. kharkov.ua /fileadmin/P SIS/ AE12 1c/ index.html.

\section{References}

1. Shulgin V.V. Teplovye akkumuljatory avtotransportnyh sredstv [Vehicular thermal accumulators]. Saint Petersburg, Polytechnic University Press Publ., 2005. 268 p.

2. Vashurkin I.O. Teplovaja podgotovka i pusk DVS mobil'nyh transportnyh i stroitel'nyh mashin zimoj [Thermal development and start of ICE of mobile vehicles and construction machinery in winter]. Saint Petersburg, Nauka Publ., 2002. 145 p.
3. Levenberg V.D. Akkumulirovanie tepla [The accumulation of heat]. Moscow, Nauka Publ., 1991. 83 p.

4. Beckman G., Gilly P. Teplovoe akkumulirovanie jenergii [Thermal accumulation of energy], Moscow, World Publ., 1987. $256 \mathrm{p}$.

5. Vlasov V.M., Nikolayev A.B., Postolit A.B., Prikhodko V.M. Informacionnye tehnologii na avtomobil'nom transporte [Information technologies in road transport]. Moscow, Nauka Publ., 2006. 283 p.

6. Prikhodko V.M. Formirovanie funkcional'nyh vozmozhnostej intellektual'noj transportnoj sistemy dlja avtomobil'nogo transporta [The formation of the functional capabilities of intelligent transport system for road transport]. Journal of Automotive Engineers, 2011, Vol. 4(69), pp. 23-27.

7. Volkov V., Mateichyk V., Nikonov O., Komov P., Gritsuk I., Volkov Ju., Komov Je. Integracija tehnicheskoj jekspluatacii avtomobilej $v$ struktury $i$ processy intellektual'nyh transportnyh sistem [The integration of automobile technical operation in the structures and processes of intelligent transport systems: monograph], Donets'k, Noulidzh Publ., 2013, 400 p.

8. Ivanov A.M., Solntsev A.N. Perspektivy razvitija intellektual'nyh bortovyh sistem avtotransportnyh sredstv $v$ Rossijskoj Federacii [Prospects for the development of intelligent on-board systems of motor vehicles in the Russian Federation]. Journal of Automotive Engineers, 2010, Vol. 6(65), pp. 14-19.

9. Przhibyl P., Svitek M. Telematika na transporte [Transport telematics], Moscow, MADI (State. Tehn. Univ) Publ., 2004, $540 \mathrm{p}$.

10. Ovsyannikov S.I. Obosnovanie struktury izmeritel'nogo kompleksa dlja provedenija tjagovyh ispytanij motoagregatov [The justification of measuring system for drag testing of motor units]. The car and electronics. Modern technology: Electronic scientific specialized edition, 2012, №3. Avialable at: http: //www.khadi.kharkov.ua /fileadmin/P SIS/AE12 1c/index.html. Aug. 2014.

Рецензент: Ф.И. Абрамчук, профессор, д.т.н., ХНАДУ. 